\title{
POLITIK HUKUM PEMBENTUKAN UU PENGADAAN TANAH UNTUK KEPENTINGAN UMUM
}

\author{
Sulasi Rongiyati \\ Peneliti Madya Bidang Hukum Pada Pusat Pengkajian Pengolahan Data dan \\ Informasi (P3DI) Setjend DPR RI \\ Email : susidhan@yahoo.com
}

\begin{abstract}
The Law No. 2/2012 on Land Acquisition Law for Public Facilities is essentially addressed by lawmakers to regulate the implementation of land acquisition for public facilities, to accommodate investors, and to provide the public with legal certainty. Under the law, the principle of balanced bargaining positions between land owners and government entity needing land is upheld. By clearly defining the terms 'public interest or facilities' and 'compensation', this assures legal certainty, respects public rights, and provides greater certainties and realizations towards public infrastructure projects going forward.
\end{abstract}

Keywords : Legal politics, land acquisition, Law No. 2/2012

\begin{abstract}
Abstrak
Politik hukum UU No. 2 Tahun 2012 tentang Pengadaan Tanah bagi Pembangunan untuk Kepentingan Umum merupakan arah kebijakan yang dibuat oleh pembentuk undang-undang dalam rangka menjembatani kebutuhan tanah untuk pembangunan kepentingan umum, kepentingan investor, dan perlindungan terhadap hak-hak masyarakat pemegang hak atas tanah. Prinsip keseimbangan posisi tawar antara pemegang hak atas tanah dan instansi yang membutuhkan tanah guna menciptakan kepastian hukum, penghormatan terhadap hak-hak masyarakat, dan terselenggaranya pembangunan untuk kepentingan umum berusaha diwujudkan dalam rumusan substansi penting seperti definisi kepentingan umum dan ganti kerugian.
\end{abstract}

Kata kunci : Politik Hukum, Pengadaan Tanah, UU No. 2 Tahun 2012

\section{A. Pendahuluan}

Tanah merupakan sumber daya penting dan strategis karena menyangkut hajat hidup orang banyak. Disamping itu tanah memiliki karakteristik yang bersifat multi dimensi, multi-sektoral, multi-disiplin, serta memiliki kompleksitas yang tinggi. Oleh karenanya masalah tanah merupakan masalah yang sarat dengan berbagai kepentingan baik ekonomi, sosial, maupun politik, bahkan untuk 
Indonesia tanah juga memiliki nilai religius yang tidak dapat diukur secara ekonomis. Seiring dengan perkembangan penduduk, kemajuan teknologi dan industri, pergeseran budaya, serta kebutuhan pembangunan lainnya maka kebutuhan akan tanah semakin meningkat, sementara tanah itu sendiri bersifat konstan. Keterbatasan tanah yang dimiliki negara untuk digunakan sebagai sarana pembangunan kepentingan umum, "memaksa" pemerintah untuk melakukan pengambilalihan tanah guna kepentingan pembangunan untuk kepentingan umum.

Politik hukum pertanahan Indonesia sebagaimana tertuang dalam Pasal 33 Ayat (3) UUD 1945 memberi kemungkinan kepada negara selaku pemegang hak menguasai dari negara untuk mengatur dan menyelenggarakan peruntukkan dan penggunaan tanah serta berwenang menentukan dan mengatur hubungan hubungan hukum antara orang dan perbuatan-perbuatan hukum yang berkaitan dengan tanah. Penjabaran dari kebijakan yang populis tersebut tertuang dalam Pasal 6 Undang-Undang Nomor 5 Tahun 1960 tentang Peraturan Dasar PokokPokok Agraria (UUPA) yang menyebutkan bahwa semua hak atas tanah mempunyai fungsi sosial. Artinya hak atas tanah tidak dapat dipergunakan untuk kepentingan pribadi semata, tetapi harus memperhatikan kepentingan masyarakat dan pemanfaatan hak atas tanah tidak boleh menimbulkan kerugian bagi masyarakat. Penggunaan tanah harus bermanfaat bagi kesejahteraan pemiliknya serta bagi masyarakat dan negara. Dengan demikian jika negara membutuhkan tanah untuk kepentingan yang lebih besar, yaitu kesejahteraan rakyat yang dilakukan melalui pelaksanaan pembangunan oleh Pemerintah, maka pemegang hak atas tanah harus bersedia melepaskan hak atas tanahnya. Dalam kaitan ini UUPA memberikan kemungkinan kepada negara untuk melakukan pengambilalihan hak atas tanah yang didasarkan pada undang-undang dengan memberikan ganti kerugian atau kompensasi yang layak bagi pemegang hak tanah yang tanahnya akan diambil alih.

Pada tataran implementasi, pada saat pemerintah membutuhkan tanah untuk kepentingan pembangunan, seringkali menemui banyak kendala. Keterbatasan ketersediaan tanah negara dan kebutuhan akan lokasi pembangunan yang hanya 
dapat dilakukan pada lokasi tertentu menjadi penyebab Pemerintah mau tidak mau harus "meminta" tanah masyarakat, melalui proses sebagaimana ditentukan dalam peraturan perundangan. Permasalahan akan muncul ketika tanah yang akan dijadikan lokasi pembangunan merupakan tempat tinggal atau sumber penghidupan utama para pemegang hak yang jika dilepaskan kepada Pemerintah akan berdampak pada penghidupan dan masa depan mereka. Konflik kepentingan antara pemegang hak atas tanah, Pemerintah, dan investor yang akan menggarap pembangunan tersebut sering kali berlarut - larut dan merugikan banyak pihak. Pada sisi lain amanat UUPA bahwa pengambilalihan tanah dilakukan melalui UU, sebelum berlakunya UU No. 2 Tahun 2012 dilakukan melalui Peraturan Pemerintah dan peraturan pelaksana lainnya.

Berdasarkan pertimbangan tersebut DPR RI bersama Pemerintah membentuk UU No. 2 Tahun 2012 tentang Pengadaan Tanah bagi Pembangunan Untuk Kepentingan Umum (UU Pengadaan Tanah). Diharapkan melalui UU ini, keadilan dan kepastian hukum dapat terwujud baik bagi masyarakat yang tanahnya diambil alih, Pemerintah dalam melaksanakan pembangunan, maupun investor yang terlibat dalam proyek pembangunan tersebut.

Berdasarkan latar belakang tersebut, maka permasalahan yang akan dibahas dalam tulisan ini adalah: Apa yang menjadi politik hukum pembentukan UU No. 2 Tahun 2012 tentang Pengadaan Tanah bagi Pembangunan untuk Kepentingan Umum? dan apa saja materi penting yang diatur dalam UU No. 2 Tahun 2012 tentang Pengadaan Tanah bagi Pembangunan untuk Kepentingan Umum?

Tulisan ini dimaksudkan untuk mengetahui politik hukum pembentukan Undang - Undang No. 2 Tahun 2012 Tentang Pengadaan Tanah bagi Pembangunan untuk Kepentingan Umum serta untuk mengetahui bagaimana undang-undang mengatur pengadaan tanah yang ditujukan bagi pembangunan untuk kepentingan umum.

Melalui tulisan ini diharapkan dapat memperluas wawasan pembaca dan menjadi referensi bagi pihak yang berkepentingan untuk mengetahui dan memahami peraturan hukum pengadaan tanah bagi pembangunan untuk kepentingan umum di Indonesia. Di samping itu terkait bidang tugas Peneliti di 
DPR RI untuk memberikan suporting system bagi Dewan dalam menjalankan tugas-tugas kedewanannya, maka tulisan ini juga diharapkan dapat menjadi bahan masukan bagi Anggota DPR dalam melaksanakan fungsi pengawasan yang berkaitan dengan kebijakan pemerintah dalam melaksanakan pembangunan, khususnya pembangunan yang berkaitan dengan bidang pertanahan.

\section{B. Pembahasan}

\section{Politik Hukum Pembentukan UU No. 2 Tahun 2012}

Politik hukum pada intinya merupakan arah kebijakan yang menjadi dasar melakukan suatu tindakan menunju pada suatu cita-cita atau tujuan yang dikehendaki. Padmo Wahyono mendefinisikan politik hukum sebagai kebijakan dasar yang menentukan arah, bentuk, maupun isi hukum yang akan dibentuk. ${ }^{1}$ Sementara Satjipto Rahardjo memandang politik hukum sebagai aktivitas memilih dan cara yang hendak dipakai untuk mencapai suatu tujuan sosial dalam hukum tertentu dalam masyarakat. Selanjutnya menurut Satjipto Rahardjo beberapa pertanyaan yang muncul dalam politik hukum adalah a) tujuan apa yang hendak dicapai dengan sistem hukum yang ada, b) cara apa yang paling baik digunakan untuk mencapai tujuan tersebut, c) Kapan dan bagaimana hukum itu dapat diubah, serta d) apakah dapat dirumuskan suatu pola baku dan mapan yang dapat membantu proses pemilihan tujuan dan cara untuk memperoleh tujuan tersebut secara baik $^{2}$. Meskipun tidak mendefinisikan politik hukum secara konkrit, Sunaryati Hartono ${ }^{3}$ dalam bukunya "Politik Hukum Menuju Satu Sistem Hukum Nasional" menjabarkan bahwa politik hukum Indonesia tidak terlepas dari realita sosial dan tradisional yang terdapat dalam negara, tetapi politik hukum Indonesia juga dipengaruhi oleh realita dan politik hukum internasional.

Berkaitan dengan politik hukum agraria nasional, Pasal 33 UUD 1945 dengan tegas menyebutkan :

"Bumi, air dan kekayaan alam yang terkandung di dalamnya dikuasai oleh negara dan digunakan untuk sebesar-besar kemakmuran rakyat".

\footnotetext{
${ }^{1}$ Dalam Imam Syaukani dan A. Ahsin Thohari, Dasar-Dasar Politik Hukum, Jakarta: PT. Raja Grafindo Persada, 2007, hal.26.

${ }^{2}$ Ibid, hal. 29.

${ }^{3}$ Sunaryati Hartono, Politik Hukum Menuju Satu Sistem Hukum Nasional, Bandung : Alumni, 1991) hal 1.
} 
Dalam konteks ini, negara dalam tingkatan tertinggi memiliki hak menguasai negara atas wilayah agraria Indonesia yang pengelolaan dan pemanfaatannya ditujukan untuk kesejahteraan rakyatnya. Politik hukum agraria yang tertuang dalam konstitusi ini kemudian dijabarkan melalui UUPA yang memiliki sifat populis. Dalam implementasinya, hukum agraria dapat dipengaruhi oleh pertimbangan ekonomi dan politik, sehingga politik agraria dapat dilihat dari prespektif ekonomi politik, yaitu suatu pendekatan yang terkait dengan pengaruh kepentingan dan pilihan nilai sosial yang dijadikan landasan kebijakan pemerintah $^{4}$.

Ketentuan Pasal 28H Ayat (4) UUD 1945 merupakan komitmen negara dalam mengakui dan menghormati hak milik perorangan, termasuk hak warga negara atas tanah. Namun hak atas tanah yang berlaku di Indonesia tidak bersifat mutlak, artinya tidak sepenuhnya dapat dipertahankan terhadap siapapun oleh pemegang hak. Dalam kondisi tertentu dimana kepentingan negara menghendaki, maka pemegang hak atas tanah harus rela melepaskan haknya untuk kepentingan yang lebih besar. Mengingat pengambilalihan tanah menyangkut hak-hak individu atau masyarakat, maka pengambilalihan tanah harus memperhatikan prinsip keadilan sehingga tidak merugikan pemilik asal. Salah satu prinsip dasar dari pengambilalihan tanah yang universal adalah 'no private property shall be taken for public use without just and fair compensation", artinya proses pengambilalihan tanah dilakukan dengan kompensasi yang jujur dan adil (Landpolicy org : 2005).

Pembentukan UU Pengadaan Tanah merupakan sejarah baru dalam hukum agraria nasional, karena selama 51 (lima puluh satu) tahun berlakunya UUPA, UU Pengadaan Tanah baru sekarang terbentuk. Seperti diketahui UUPA tidak mengatur secara detail ketentuan mengenai pengadaan tanah untuk kepentingan umum. Instrumen hukum yang tersedia pada waktu itu adalah Keputusan Presiden No. 55 tahun 1993 tentang Pengadaan Tanah Bagi Pelaksanaan Pembangunan Untuk Kepentingan Umum (Keppres No. 55 Tahun 1993). Substansi Keppres 55

\footnotetext{
${ }^{4}$ Moh. Mafud MD, Membangun Politik Hukum, Menegakkan Konstitusi, Jakarta : Rajawali Pers, 2011, hal. 248 .
} 
Tahun 1993 dipandang kurang memiliki keberpihakan kepada rakyat. Dalam banyak kasus masyarakat "dipaksa" melepaskan hak atas tanahnya dengan dalih untuk kepentingan umum. Alih-alih bisa meningkatkan tingkat kesejahteraan pemilik tanah asal, penggusuran atas tanah mereka bahkan membawa petaka bagi masa depan mereka, karena harus kehilangan sumber penghidupannya, sementara uang ganti rugi tidak cukup untuk membeli tanah yang nilai ekonomi maupun sosialnya setara dengan tanah yang digusur. Kondisi tersebut terjadi, salah satunya disebabkan adanya ketentuan yang memberikan "blanko kosong" kepada Presiden untuk menentukan kegiatan pembangunan yang termasuk dalam kategori Kepentingan Umum melalui Keputusan Presiden. Disamping itu, dominasi Pemerintah dalam menentukan dan menetapkan besarnya ganti rugi tanpa melibatkan masyarakat yang terkena dampak secara proposional juga menjadi pendorong penolakan masyarakat terhadap kegiatan - kegiatan pembangunan untuk kepentingan umum yang membutuhkan pengadaan tanah.

Era reformasi telah mengubah paradigma masyarakat untuk berani menuntut dan memperjuangkan hak-haknya, termasuk di bidang agraria. Salah satunya dengan tuntutan memperbaiki ketentuan pengadaan tanah untuk kepentingan umum, yang kemudian direspon oleh Pemerintah dengan mengeluarkan Peraturan Presiden No. 65 Tahun 2006 jo Perpres No. 36 Tahun 2005 tentang Pengadaan Tanah bagi Pelaksanaan Pembangunan. Meskipun dalam Perpres ini jenis kepentingan umum disebutkan secara limitatif, namun Perpres inipun dipandang memiliki kelemahan antara lain keberadaan Panitia Musyawarah yang seluruh anggotanya berasal dari jajaran pemerintah akan mempengaruhi obyektifitas hasil musyawarah dan kecenderungannya Panitia Musyawarah tidak bertindak sebagai mediator tetapi justru seolah-olah bertindak sebagai pihak yang membutuhkan tanah.

Melalui UU Pengadaan Tanah diharapkan terjadi keseimbangan posisi tawar antara pemegang hak atas tanah dengan instansi yang membutuhkan tanah sehingga pembangunan untuk kepentingan umum tetap berjalan, hak-hak rakyat tetap dihormati, dan kepastian hukum bagi investor maupun masyarakat dapat terujud. 


\section{Pembentukan Hukum dan Substansi Hukum}

Pembentukan hukum termasuk undang - undang, tidak terlepas dari proses penyusunannya yang pada umumnya didasari oleh pertimbangan atau alasan filosofis, yuridis, dan sosiologis. Namun pada intinya proses penyusunan undangundang dapat digolongkan dalam dua tahapan besar, yaitu tahap sosiologis dan tahap yuridis. Pada tahap sosiologis berlangsung proses untuk mematangkan masalah, sehingga dapat masuk ke dalam agenda yuridis, sedangkan pada tahap yuridis dilakukan proses perumusan substansi undang-undangnya. Dalam dua tahapan tersebut pihak-pihak yang memiliki kepentingan akan berusaha "turut masuk" ke dalam pekerjaan pembentukan undang-undang. ${ }^{5}$

Pembentukan undang-undang merupakan salah satu bentuk pembaruan hukum sebagai upaya menyesuaikan perkembangan dan tuntutan kebutuhan masyarakat. Di negara-negara berkembang, pembaruan hukum merupakan prioritas utama dalam melakukan pembangunan, sebab pada umumnya pembaruan hukum tersebut memiliki peran ganda, yaitu $:^{6}$

a. merupakan upaya melepaskan diri dari struktur hukum kolonial. Hal ini biasanya dilakukan melalui penggantian, penghapusan,dan penyesuaian hukum warisan kolonial untuk memenuhi tuntutan masyarakat nasional; dan b. mendorong proses pembangunan, terutama pembangunan bidang ekonomi. Peran pembaruan hukum dalam kaitan ini dilakukan dalam rangka meningkatkan kesejahteraan warga negaranya serta guna mengejar

ketertinggalan pembangunan ekonomi dari negara - negara maju.

Unsur utama hukum meliputi ketertiban, keadilan, dan kepastian ${ }^{7}$, oleh karenanya pembentukan hukum harus mampu mencerminkan ketiga unsur tersebut. Hukum itu sendiri akan terus berkembang sesuai dengan perkembangan masyarakat dan karakter hukum itu sendiri dipengaruhi oleh variabel yang

${ }^{5}$ Satjipto Rahardjo, Sisi-Sisi Lain dari Hukum di Indonesia, (Jakarta : Penerbit Buku Kompas, 2003), hal. 129-131.

${ }^{6}$ Mulhadi, Relevansi Teori Sosiological Yurisprudensi dalam Upaya Pembaharuan Hukum di Indonesia, hal 5. www.search-ebooks.com diakses tanggal 4 Juni 2010

${ }^{7}$ Johnny Ibrahim, Pendekatan Ekonomi Terhadap Hukum : Teori dan Implikasi Penerapannya dalam penegakan Hukum, Surabaya : Putra Media Nusantara dan ITSPress Surabaya, 2009, hal. 16-23. 
berbeda sesuai dengan konteks perubahanannya. Menurut Philippe Nonet dan Philip Selznick, ${ }^{8}$ variabel yang terkait dengan hukum tersebut adalah peran paksaan dalam hukum, hubungan timbal balik antara hukum dan politik, hubungan hukum dengan negara dan tertib moral, letak peraturan, diskresi, tujuan dalam putusan hukum, partisipasi masyarakat, legitimasi, dan ketaatan. Antarvariabel tersebut memiliki keterkaitan yang sistematis, jelas, serta tergantung pada kondisi yang pada akhirnya akan membentuk sistem dengan susunan karakter - karakter yang memiliki keterkaitan secara internal. Terdapat tiga karakteristik hukum dalam masyarakat yaitu: hukum represif; hukum otonom; dan hukum responsif.

Hukum represif, lebih mengarah pada model hukum yang mengedepankan pelayanan kekuasaan dan menafikan aspirasi publik, dengan ciri utama: (a) kekuasaan politik mengatasi institusi hukum, sehingga kekuasaan negara menjadi legitimasi hukum, (b) penyelenggaraan hukum dijalankan berdasarkan perspektif penguasa dan pejabat (menempatkan ketertiban sebagai tujuan utama hukum dan mementingkan kemudahan administrasi, (c) peraturan bersifat diskriminatif, represif terhadap rakyat tetapi lunak terhadap penguasa, (d) alasan pembentukannya bersifat ad hoc sesuai dengan keinginan arbitrer penguasa, (e) kesempatan bertindak bersifat meresap sesuai kesempatan, (f) pemaksaan meliputi keseluruhan, tanpa batas yang jelas, (g) menuntut pengendalian diri dari masyarakat, (h) kepatuhan masyarakat harus tanpa syarat dan ketidakpatuhan hukum dianggap sebagai kejahatan, dan (i) partisipasi masyarakat dimungkinkan melalui penundukan diri dan kritik dipahami sebagai tindakan pembangkangan. ${ }^{9}$

Hukum otonom, berintikan supremasi aturan dan prosedur sehingga masalah keadilan hanya dimaknai sebatas keadilan prosedural. Tipe tatanan hukum otonom ini memperlihatkan ciri: (1) hukum terpisah dari kekuasaan, (2) aturan menjadi satu-satunya dasar penilaian dan tanggungjawab hukum, (3) prosedur dipandang sebagai inti hukum, sehingga tujuan dan kompetensi utama hukum adalah

\footnotetext{
${ }^{8}$ Philippe Nonet dan Philip Selznick, Hukum Responsif Pilihan di Masa Transisi (Law and Society in Transition : Toward Responsive Law), diterjemahkan oleh Rafael Edy Bosco (Jakarta : HuMa, 2003), hal.1113

${ }^{9}$ Philippe Nonet dan Philip Selznick, dalam Bernard L. Tanya dkk, Teori Hukum Strategi Tertib Manusia Lintas Ruang dan Generasi, (Yogyakarta : Genta Publishing, 2010), hal. 207-208
} 
regulasi, (4) loyalitas pada hukum bermakna sama pada kepatuhan pada aturan hukum positif, (5) diskresi dibatasi karena dapat merongrong integritas proses hukum, (6) mengutamakan formalisme dan legalisme, (7) kritik terhadap aturan hukum harus melalui proses legislasi. ${ }^{10}$

Hukum responsif, menempatkan hukum sebagai sarana respons terhadap ketentuan - ketentuan sosial dan sarana publik. Sesuai dengan sifatnya yang terbuka maka tipe hukum responsif mengedepankan akomodasi untuk menerima perubahan-perubahan sosial dalam rangka mencapai tujuan keadilan dan emansipasi publik. Hukum responsif menekankan hal-hal sebagai berikut: (a) keadilan substansif sebagai dasar legitimasi hukum, (b). Peraturan merupakan sub-ordinasi dari prinsip dan kebijakan, (c) pertimbangan hukum berorientasi pada tujuan dan akibat bagi kemaslahatan masyarakat, (d) Menganjurkan diskresi pada pengambilan keputusan hukum engan tetap berorientasi pada tujuan, (e). Memupuk sistem kewajiban sebagai pengganti paksaan, (f) Moralitas kerjasama sebagai prinsip moral menjalankan hukum, (g) kekuasaan didayagunakan untuk mendukung vitalitas hukum dalam melayani masyarakat, (h) Penolakan terhadap hukum dianggap sebagai gugatan terhadap legitimasi hukum, (i) Akses partisipasi publik terbuka dalam rangka integrasi advokasi hukum dan sosial. ${ }^{11}$

Secara keseluruhan banyak sekali kemajuan pengaturan pengadaan tanah yang diatur dalam UU Pengadaan Tanah baik dari ruang lingkup kepentingan umum maupun proses pengadaan tanah yang dimulai dari tahap persiapan, perencanaan, pelaksanaan, dan penyerahan hasil serta pengawasan dan evaluasi.

Jika Perpres No. 36 Tahun 2005 menuai kontroversi yang bersumber pada luasnya definisi kepentingan umum dan jaminan ganti kerugian yang dianggap merugikan masyarakat yang tanahnya diambil alih untuk kegiatan pembangunan demi kepentingan umum, dan kemudian Perpres No. 65 Tahun 2006 tentang Perubahan Perpres No. 36 Tahun 2005 dianggap kurang memiliki kepastian hukum dan jaminan pelaksanaan pembangunan untuk kepentingan umum, maka

\footnotetext{
${ }^{10}$ Ibid, hal. 209

${ }^{11}$ Ibid, hal. 205-207
} 
secara garis besar, UU Pengadaan Tanah memiliki kedudukan hukum yang lebih kuat dibanding peraturan pengadaan tanah yang pernah ada sebelumnya.

Sedang dari sisi substansi UU Pengadaan Tanah lebih bersifat komprehensif dan memiliki kepastian hukum dan mengedepankan rasa keadilan bagi masyarakat. Hal ini nampak pada beberapa substansi krusial yang berusaha mengakomodasi berbagai kepentingan stakeholder, seperti penetapan jangka waktu yang ketat mulai dari proses perencanaan, persiapan, pelaksanaan hinggatahap penyerahan hasil pengadaan tanah. Hal ini dimaksudkan agar pemerintah maupun investor memiliki pepastian hukum atas proyek yang akan dikerjakannya. Kepastian hukum juga tercermin pada kewajiban penyelenggaraan pengadaan tanah untuk kepentingan umum harus sesuai dengan: ${ }^{12}$

a. Rencana Tata Ruang Wilayah;

b. Rencana Pembangunan Nasional/Daerah;

c. Rencana Strategis; dan

d. Rencana Kerja setiap Instansi yang memerlukan tanah.

Sedangkan dari sisi masyarakat yang terkena dampak pengadaan tanah bagi kegiatan pembangunan untuk kepentingan umum, jenis ganti kerugian yang tidak terbatas pada uang ganti rugi atau lahan pengganti, tetapi dimungkinkan adanya bentuk ganti kerugian lain yang disepakati oleh para pihak dirasa lebih memberikan rasa keadilan masyarakat.

\section{Materi-Materi Krusial dalam UU Pengadaan Tanah}

Rancangan Undang - Undang Pengadaan Tanah merupakan RUU yang berasal dari Pemerintah. Meskipun dalam pembahasan internal dai Tim Pemerintah sudah melalui kajian mendalam dengan melibatkan kementerian dan instansi terkait lainnya serta sudah melalui tahapan sosialisasi dan penjaringan masukan dari berbagai sumber yang memahai benar persoalan pertanahan, namun mengingat komleksitas substansi dan besarnya dampak ekonomi, sosial, maupun hukum dari penyelenggaraan pengadaan tanah untuk kepentingan mum ini, maka Pansus DPR RI berusaha untuk memperoleh masukan dari berbagai pihak yang

\footnotetext{
${ }^{12}$ Pasal 7 UU Pengadaan Tanah
} 
terkait baik Instansi Pemerintah / Daerah, BUMN/BHMN, akademisi, maupun LSM. Semua itu semata-mata karena Pansus menginginkan UU Pengadaan Tanah memiliki kepedulian terhadap hak-hak rakyat, memberi kepastian pada investor, serta menjamin pelaksanaan pembangunan yang telah direncanakan oleh pemerintah.

Dalam perjalanan pembahasan RUU PTUP, terdapat beberapa substansi krusial yang menjadi diskusi panjang dan alot dalam rapat-rapat Pansus. Selain mengenai definisi dan jenis Kepentingan Umum beberapa substansi penting yang didalami Pansus secara khusus dan intensif antara lain meliputi, definisi Instansi, Lembaga Pertanahan sebagai pelaksana pengadaan tanah untuk pembangunan, jenis-jenis ganti kerugian atau kompensasi, serta masalah perlindungan dan penggunaan hak-hak hukum para pihak.

Kepentingan Umum : Pengaturan jelas dan tegas mengenai Kepentingan Umum menjadi concern pembahasan Pansus RUU PTUP. Hal ini didasari kekhawatiran "kepentingan umum" hanya dijadikan dalih untuk mengambil alih tanah rakyat guna kepentingan segelintir/sekelompok orang tertentu. Pada sisi lainnya Pansus RUU PTUP menyadari perlunya memperhatikan kebutuhankebutuhan pembangunan yang dibutuhkan masyarakat, yang menjadi tanggungjawab pemerintah untuk menyediakannya. Oleh karenanya pengertian dan kriteria Kepentingan Umum harus mampu mengakomodir kebutuhan pembangunan yang menjadi tugas dan tanggungjawab pemerintah dengan tujuan utama meningkatkan kesejahteraan dan kemakmuran rakyatnya.

Dalam UU Pengadaan Tanah, Kepentingan Umum didefinisikan sebagai "kepentingan bangsa, negara, dan masyarakat yang harus diwujudkan oleh pemerintah dan digunakan sebesar-besarnya untuk kemakmuran rakyat." Sedangkan mengenai peruntukan pengadaan tanah untuk kepentingan umum, disepakati 18 (delapan) jenis kegiatan pembangunan yang dikategorikan sebagai kepentingan umum meliputi :

a. pertahanan dan keamanan nasional;

b. jalan umum, jalan tol, terowongan, jalur kereta api, stasiun kereta api, dan fasilitas operasi kereta api; 
c. waduk, bendungan, bendung, irigasi, saluran air minum, saluran pembuangan air dan sanitasi, dan bangunan pengairan lainnya

d. pelabuhan, bandar udara, dan terminal;

e. infrastruktur minyak, gas, dan panas bumi;

f. pembangkit, transmisi, gardu, jaringan, dan distribusi tenaga listrik;

g. jaringan telekomunikasi dan informatika Pemerintah;

h. tempat pembuangan dan pengolahan sampah;

i. rumah sakit Pemerintah / Pemerintah Daerah;

j. fasilitas keselamatan umum;

k. tempat pemakaman umum Pemerintah/Pemerintah Daerah;

1. fasilitas sosial, fasilitas umum, dan ruang terbuka hijau publik;

m. cagar alam dan cagar budaya;

n. kantor Pemerintah / Pemerintah Daerah / desa;

o. penataan permukiman kumuh perkotaan dan / atau konsolidasi tanah, serta perumahan untuk masyarakat berpenghasilan rendah dengan status sewa;

p. prasarana pendidikan atau sekolah Pemerintah / Pemerintah Daerah;

q. prasarana olahraga Pemerintah / Pemerintah Daerah; dan

r. pasar umum dan lapangan parkir umum.

Jika dibandingkan dengan jenis Kepentingan Umum dalam Perpres No.65 Tahun 2006, UU Pengadaan Tanah berusaha menjawab kebutuhan - kebutuhan pembangunan yang selama ini tidak terakomodasi sebagai Kepentingan Umum, seperti pembangunan rumah sakit dan sekolah milik Pemerintah/Daerah yang secara faktual sangat dibutuhkan oleh masyarakat dan menjadi kewajiban Pemerintah untuk menyelenggarakannya.

Pengertian Instansi : Pada awalnya RUU PTUP membatasi pengertian instansi hanya terbatas pada instansi pemerintah baik pusat maupun daerah, namun Pansus melihat fakta di lapangan yang menunjukan kebutuhan pengadaan tanah untuk kepentingan umum oleh Badan Usaha Milik Negara (BUMN) atau Badan Hukum Milik Negara (BHMN) tertentu yang memang dibutuhkan oleh rakyat banyak, seperti pembangkit dan transmisi listrik yang dilakukan PLN maka 
setelah melalui diskusi mendalam disepakati rumusan Instansi sebagai "lembaga negara, kementerian dan lembaga pemerintah nonkementerian, pemerintah provinsi, pemerintah kabupaten / kota, dan Badan Hukum Milik Negara / Badan Usaha Milik Negara yang mendapat penugasan khusus Pemerintah". Penugasan khusus dari Pemerintah menjadi persyaratan, mengingat tidak semua BUMN dapat dikategorikan melayani Kepentingan umum. Definisi tersebut membawa konsekuensi pada pendanaan dan aset kepemilikan obyek pengadaan tanah. Pada prinsipnya Pengadaan Tanah untuk Kepentingan Umum wajib diselenggarakan oleh Pemerintah dan tanahnya selanjutnya dimiliki Pemerintah atau Pemerintah Daerah. Namun dalam hal Instansi yang memerlukan Pengadaan Tanah untuk Kepentingan Umum adalah BUMN, tanahnya menjadi milik BUMN.

Jenis ganti kerugian : Masyarakat yang tanahnya digunakan bagi pembangunan untuk kepentingan umum, pasti tidak hanya mengalami kerugian secara fisik tetapi juga kerugian non fisik. Oleh karena itu ganti kerugian dalam UU Pengadaan Tanah dirumuskan tidak hanya dalam bentuk uang, tetapi memberikan pilihan atas jenis dan bentuk ganti kerugian lainnya yaitu dapat berupa uang, tanah pengganti, permukiman kembali, kepemilikan saham, atau bentuk lain yang disetujui oleh kedua belah pihak.

Dalam Pembahasan di tingkat Pansus, Fraksi-Fraksi secara umum menyepakati ketentuan Ganti Kerugian yang sifatnya pilihan atau opsional sesuai dengan kesepakatan pihak yang membutuhkan tanah dengan Pihak yang Berhak. Secara khusus ditekankan bahwa bentuk ganti kerugian berupa kepemilikan saham merupakan terobosan yang progresif dalam pelaksanaan pemberian ganti kerugian. Dengan adanya pilihan nilai dan bentuk Ganti Kerugian seperti di atas, dipastikan akan mendorong terjadinya konsultasi publik maupun musyawarah antara masyarakat dengan pemerintah secara terbuka dan dialogis. Dengan permusyawaratan tersebut, maka pilihan atas jenis dan bentuk ganti kerugian ditentukan atas kesadaran pilihan masyarakat dan pilihannya tersebut yang kemudian diterima oleh pemerintah adalah sebagai bagian dari prinsip dasar Pemerintah dalam melindungi rakyatnya di tempat pembangunan untuk kepentingan umum akan dilaksanakan. 
Perlindungan dan penggunaan hak-hak hukum : Guna mencapai kesepakatan dan kesepahaman dalam pengadaan tanah, UU Pengadaan Tanah memberikan ruang luas bagi para pihak untuk memperjuangkan hak-haknya, mulai dari konsultasi publik, pembentukan Tim Pengkaji, hingga upaya melalui jalur pengadilan. Konsultasi Publik merupakan proses komunikasi dialogis atau musyawarah antarpihak yang berkepentingan guna mencapai kesepahaman dan kesepakatan dalam perencanaan pengadaan tanah bagi pembangunan untuk kepentingan umum. Apabila konsultasi publik yang dilakukan tidak mencapai titik temu karena masih terdapat pihak yang keberatan, Gubernur membentuk Tim untuk mengkaji keberatan yang diajukan oleh pihak yang berkeberatan. Berdasarkan rekomendasi Tim Pengkaji tersebut Gubernur mengeluarkan surat diterima atau ditolaknya keberatan atas rencana lokasi pembangunan. Dengan demikian hak-hak masyarakat terhadap keberatan rencana pengadaan tanah yang akan digunakan sebagai lokasi pembangunan untuk kepentingan umum dijamin dengan adanya kesempatan untuk mengajukan gugatan atas penetapan lokasi rencana pembangunan.

Pentahapan Pengadaan Tanah : Secara garis besar UU Pengadaan Tanah secara komprehensif mengatur penyelenggaraan pengadaan tanah untuk kepentingan umum melalui proses pentahapan yang pasti dan berurutan, yaitu meliputi tahap perencanaan, persiapan, dan pelaksanaan. Dengan demikian pengadaan tanah yang diselenggarakan oleh Pemerintah harus memiliki perencanaan yang matang, pelaksanaan yang sesuai dengan ketentuan peraturan perundang-undangan serta diikuti dengan pemantauan dan evaluasi. Hal tersebut dimaksudkan agar tercipta keadilan dan kepastian hukum sesuai dengan tujuan pengadaan tanah yaitu menyediakan tanah bagi pelaksanaan pembangunan untuk kepentingan umum guna meningkatkan kesejahteraan dan kemakmuran bangsa, negara dan masyarakat dengan tetap menjamin kepentingan hukum pihak yang berhak. Jangka waktu proses pengadaan tanah dari tahap perencanaan, persiapan, penetapan lokasi sampai tahap pengendalian kurang lebih membutuhkan waktu 4 tahun 5 bulan 


\section{Pembentukan Panitia Pelaksana dan Pembiayaan Pengadaan Tanah} bagi Pembangunan untuk Kepentingan Umum : Berbeda dengan peraturan perundangan sebelumnya, dalam UU Pengadaan Tanah tidak menyebut istilah "Panitia Pelaksana Pengadaan Tanah". Hal ini dikarenakan UU Pengadaan Tanah tidak memberikan kewenangan pelaksanaan pengadaan tanah kepada satu lembaga ataupun kepanitiaan secara khusus, tetapi melibatkan Lembaga Pertanahan, dalam hal ini dijabat oleh Badan Pertanahan Nasional sebagai lembaga pemerintah yang menyelenggarakan urusan pemerintahan di bidang pertanahan, Pemerintah Daerah, dan Instansi yang membutuhkan tanah. Dengan demikian pelaksanaan pengadaan tanah menjadi kewenangan Lembaga pertanahan dan gubernur.

Keterlibatan pemerintah daerah menunjukan political will pembentuk undang-undang dengan harapan pelaksanaan pengadaan tanah yang didasarkan pada UU Pengadaan Tanah ini, benar - benar sesuai dengan tujuan yang diharapkan yaitu menyediakan tanah bagi pelaksanaan pembangunan guna meningkatkan kesejahteraan dan kemakmuran bangsa, negara, dan masyarakat dengan tetap menjamin kepentingan hukum pihak yang berhak. Sebagaimana diketahui, draf awal RUU PTUP menempatkan BPN sebagai satu-satunya lembaga yang memiliki kewenangan luas dalam pengadaan tanah mulai dari konsultasi publik hingga menilai ganti rugi, namun berbagai masukkan dari masyarakat maupun pemerintah daerah pada saat UU ini di bahas di tingkat Pansus telah mendorong DPR untuk mengakomodasi harapan masyarakat luas agar daerah sebagai pemangku kepentingan yang secara langsung berhadapan dengan masyarakat pemilik tanah, untuk dilibatkan dalam proses pelaksanaan pegadaan tanah sejak. Hal ini juga sejalan dengan pelaksanaan otonomi daerah yang diatur dalam UU No.32 tahun 2004 tentang Pemerintahan Daerah dan PP No.38 tahun 2007 tentang Pembagian urusan Pemerintahan antara Pemerintah Pusat, Pemerintah Provinsi dan Pemerintah Kabupaten / Kota yang menempatkan bidang pertanahan sebagai urusan pemerintah yang diserahkan kepada daerah. Pemberian kewenangan yang luas kepada BPN juga dikhawatirkan akan menyebabkan tumpang tindih kewenangan dalam proses pengadaan tanah, 
mengingat BPN hanya menjalankan tugas administrasi pertanahan, sedangkan yang terlibat langsung dan memahami persoalan tanah adalah pemda, pada sisi lain pengadaan tanah sangat terkait dengan berbagai kebijakan pemerintah daerah seperti pengelolaan tata ruang, perencanaan pembangunan daerah, perijinan dan sebagainya.

Selanjutnya mengenai pembiayaan / pendanaan, UU Pengadaan Tanah mengamanatkan masalah pendanaan pengadaan tanah yang meliputi tahap perencanaan; persiapan; pelaksanaan; penyerahan hasil; administrasi dan pengelolaan; dan sosialisasi dijamin ketersediannya oleh Instansi (Pasal 52) dan secara eksplisit disebutkan 3 (tiga) sumber pendanaan pengadaan tanah, yaitu :

1. Anggaran Pendapatan dan Belanja Negara (APBN);

2. Anggaran Pendapatan dan Belanja Daerah (APBD); dan / atau

3. Internal perusahaan atau sumber lain sesuai dengan ketentuan peraturan perundang-undangan, dalam hal Instansi yang memerlukan tanah adalah Badan Hukum Milik Negara / Badan Usaha Milik Negara yang mendapatkan penugasan khusus.

Sumber pendanaan dari internal perusahaan merupakan konsekuensi dari definisi Instansi yang meliputi : lembaga negara, kementerian dan lembaga pemerintah nonkementerian, pemerintah provinsi, pemerintah kabupaten / kota, dan Badan Hukum Milik Negara / Badan Usaha Milik Negara yang mendapat penugasan khusus Pemerintah.

Pembentukan Lembaga Penilai Tanah : Dalam sejarah pengadaan tanah bagi pembangunan untuk kepentingan umum masalah Lembaga Penilai atau Tim Penilai Harga Tanah baru dikenal pada Perpres Nomor 36 Tahun 2005. Dalam Kepres Nomor 55 Tahun 1993 tugas untuk melakukan penilaian harga terhadap tanah dan objek lainnya masih menjadi tugas dan kewenangan panitia pegadaan tanah, sebagaimana tercantum dalam Pasal 8 kepres No. 55 tahun 1993, sehingga implementasi sering lebih berpihak pada pihak yang membutuhkan tanah. Dalam Perpres Nomor 36 tahun 2005 mengenai Lembaga atau Tim Penilai Tanah diatur tersendiri di luar tugas dan kewenangan Panitia Pengadaan Tanah. Meskipun Panitia Pengadaan Tanah harus berkoordinasi dengan Lembaga/ Tim Penilai 
Harga Tanah sebagai salah satu mekanisme pengadaan tanah yang dilakukan oleh panitia pengadaan tanah tersebut.

Ketentuan Umum Pasal 1 ayat 12 Perpres Nomor 36 Tahun 2005 menegaskan bahwa Lembaga / Tim Penilai Harga Tanah adalah lembaga atau tim yang professional dan independen untuk menentukan nilai / harga tanah yang akan digunakan sebagai dasar guna mencapai kesepakatan atas jumlah / besarnya ganti rugi. Ketentuan ini diperjelas dalam Peraturan Kepala Badan Pertanahan Nasional (PerKaBPN) Nomor 3 Tahun 2007 dengan memisahkan pengertian Lembaga Penilai Harga Tanah dan Tim Penilai Harga Tanah. Lembaga Penilai Harga Tanah adalah lembaga profesional dan independen yang mempunyai keahlian dan kemampuan di bidang penilaian harga tanah. Sedangkan Tim Penilai Harga Tanah adalah tim yang dibentuk dengan Keputusan Bupati / Walikota atau Gubernur untuk wilayah Daerah Khusus Ibukota Jakarta untuk menilai harga tanah, apabila di wilayah kabupaten / kota yang bersangkutan atau sekitarnya tidak terdapat Lembaga Penilai Harga Tanah.

Namun baik Perpres Nomor 36 Tahun 2005 maupun Perpres Nomor 65 Tahun 2006, tugas dan wewenang lembaga penilai atau tim penilai harga tanah belum ditegaskan secara jelas. Pasal 15 ayat 2 hanya menyebutkan bahwa dalam rangka menetapkan dasar ganti rugi, Lembaga / Tim Penilai Harga Tanah ditetapkan oleh bupati / walikota atau gubernur bagi Provinsi Daerah Khusus Ibukota Jakarta. Dengan demikian lembaga ini bersifat pasif karena penentuan dasar penghitungan ganti rugi tetap dikembalikan ke pemerintah. Perpres juga tidak menyebutkan secara jelas siapa yang memiliki kewenangan untuk menghitung besarnya ganti rugi terhadap pengadaan tanah untuk kepentingan umum.

Tugas dan kewenangan Tim Penilai baru tergambar jelas dalam Pasal 28 Peraturan Perka BPN Nomor 3 Tahun 2007 yang menegaskan Tim Penilai Harga Tanah melakukan penilaian harga tanah berdasarkan pada Nilai Jual Obyek Pajak (NJOP) atau nilai nyata / sebenarnya dengan memperhatikan NJOP tahun berjalan, dan dapat berpedoman pada variabel-variabel tertentu antara lain lokasi dan letak tanah, status tanah, peruntukan tanah dan faktor lainnya yang 
mempengaruhi harga tanah. Selanjutnya penilaian tersebut diserahkan kepada Panitia Pengadaan Tanah Kabupaten / Kota. Untuk dipergunakan sebagai dasar musyawarah antara instansi pemerintah yang memerlukan tanah dengan pemegang hak.

Dalam UU Pengadaan Tanah bagi Pembangunan untuk Kepentingan Umum, Lembaga Penilai merupakan point penting yang dibahas dalam Pansus RUU PTUP. Dalam pandangan Pansus, keberadaan Penilai sebagai pihak yang bertugas melakukan penilaian terhadap tanah yang akan digunakan untuk kepentingan umum sangat menentukan nilai ganti kerugian yang akan diterima kepada pemegang hak atas tanah. Terlebih penilaian yang dilakukannya akan digunakan sebagai dasar musyawarah untuk menetapkan nilai ganti kerugian. Oleh karenanya Penilai yang profesional dan kredibel mutlak diperlukan jika ingin penyelenggaraan pengadaan tanah benar-benar mengedepankan prinsip kemanusiaan, demokrasi dan keadilan yang mencerminkan keseimbangan hak pemegang hak atas tanah dengan instansi yang membutuhkan tanah. Pasal 32 UU Pengadaan Tanah menyebutkan bahwa Penilai objek pengadaan tanah merupakan Penilai yang diatur dalam peraturan perundang-undangan dan harus mendapatkan penetapan dari Lembaga Pertanahan. Dalam melaksanakan tugasnya Penilai wajib bertanggung jawab terhadap penilaian yang telah dilaksanakan dan pelanggaran terhadap kewajiban Penilai tersebut dikenakan sanksi administratif dan/atau pidana sesuai dengan ketentuan peraturan perundang - undangan.

\section{Penutup}

\section{A. Kesimpulan}

Pembentukan UU Pengadaan Tanah memiliki dua dimensi, pada satu sisi pembangunan untuk kepentingan umum merupakan salah satu pelaksanaan tugas Pemerintah yang diamanatkan konstitusi guna memberikan kesejahteraan kepada masyarakat dan untuk terlaksananya pembangunan tersebut diperlukan tanah sebagai unsur utamanya. Pada sisi yang lain, keterbatasan ketersediaan tanah yang dimiliki Pemerintah menyebabkan perlunya pengadaan tanah yang diperoleh dari masyarakat. UU Pengadaan Tanah memberikan arah kebijakan sebagai acuan 
mewujudkan cita - cita pembangunan untuk kepentingan umum yang berusaha mengedepankan keseimbangan posisi tawar antara pemegang hak atas tanah dengan instansi yang membutuhkan tanah sehingga pembangunan untuk kepentingan umum tetap berjalan, hak-hak rakyat tetap dihormati, dan kepastian hukum bagi investor maupun masyarakat dapat terujud. UU Pengadaan Tanah lebih bersifat komprehensif, memiliki kekuatan mengikat lebih kuat serta lebih berkepastian hukum dan mengedepankan rasa keadilan bagi masyarakat dibandingkan dengan peraturan - peraturan pengadaan tanah yang pernah berlaku sebelumnya.

Beberapa substansi krusial yang menjadi pengaturan UU Pengadaan Tanah memiliki kelebihan jika dibandingkan dengan Perpres 65 Tahun 2006 antara lain :

a. Definisi dan jenis kepentingan umum jelas dan tidak membuka peluang terhadap penafsiran "Kepentingan Umum" di luar UU;

b. Peluang pihak yang memiliki tanah untuk memperjuangkan hak-haknya lebih luas dan terbuka, melalui konsultasi publik, pengajuan keberatan, dan jalur pengadilan;

c. Jenis ganti kerugian yang bersifat alternatif, sesuai dengan keinginan pihak yang tanahnya digunakan bagi pembangunan untuk Kepentingan Umum;

d. Adanya kewajiban Penilai Tanah yang profesional dan independent serta memiliki tugas dan tanggungjawab yang jelas;

e. Proses pengadaan tanah dilakukan dengan pentahapan dan jangka waktu yang jelas dan pasti.

\section{B. Saran}

Berbagai tujuan yang menjiwai UU Pengadaan Tanah masih perlu dibuktikan dalam pelaksanaannya. Oleh karenanya pengawasan dalam pelaksanaan pengadaan tanah bagi pembangunan untuk kepentingan umum mutlak diperlukan, khususnya terkait dengan independensi Lembaga Pertanahan yang menjadi kewenangan Badan Pertanahan Nasional. Berbagai peraturan pelaksana juga harus disesuaikan dengan jiwa dan semangat UU Pengadaan Tanah. Beberapa substansi penting yang memiliki kelemahan perlu 
disempurnakan seperti belum adanya metode penilaian harga/nilai tanah yang dapat dijadikan standar bagi Penilai Tanah dalam menentukan besarnya ganti kerugian.

\section{DAFTAR PUSTAKA}

Syaukani, Imam dan A. Ahsin Thohari. Dasar - Dasar Politik Hukum, Jakarta : PT.Raja Grafindo Persada, 2007.

Hartono,Sunaryati. Politik Hukum Menuju Satu Sistem Hukum Nasional, Bandung : Alumni, 1991)

Ibrahim, Johnny. Pendekatan Ekonomi Terhadap Hukum : Teori dan Implikasi Penerapannya dalam penegakan Hukum, Surabaya : Putra Media Nusantara dan ITS Press Surabaya, 2009.

Mafud, Moh. MD. Membangun Politik Hukum, Menegakkan Konstitusi, Jakarta: Rajawali Pers, 2011,

Mulhadi, Relevansi Teori Sosiological Yurisprudensi dalam Upaya Pembaharuan Hukum di Indonesia, www.search-ebooks.com diakses tanggal 4 Juni 2010

Nonet, Philippe dan Philip Selznick. Hukum Responsif Pilihan di Masa Transisi (Law and Society in Transition : Toward Responsive Law), diterjemahkan oleh Rafael Edy Bosco (Jakarta : HuMa, 2003).

Rahardjo, Satjipto. Sisi - Sisi Lain dari Hukum di Indonesia, (Jakarta : Penerbit Buku Kompas, 2003).

Tanya, Bernard L. dkk, Teori Hukum Strategi Tertib Manusia Lintas Ruang dan Generasi, (Yogyakarta : Genta Publishing, 2010).

Indonesia, Undang - Undang tentang Pengadaan Tanah Bagi Pembangunan untuk Kepentingan Umum, UU No. 2 Tahun 2012, LN No. 22 TLN No.5280.

-, Peraturan Presiden tentang Perubahan atas Peraturan Presiden No. 36 Tahun 2005 tentang Pengadaan Tanah bagi Pelaksanaan Pembangunan, Perpres No. 65 Tahun 2006.

------------, Peraturan Presiden tentang Pengadaan Tanah bagi Pelaksanaan Pembangunan, Perpres No. 36 Tahun 2005. 